\title{
DEVELOPED VISION IN ONLINE TEACHING OF FASHION COURSES: FABRICS DYEING AS A MODEL
}

\author{
Rehab Ragab Mahmoud Hassaan \\ Prof. Dr., University of Nizwa, Oman. Helwan University, Egypt \\ rehab.ragab@unizwa.edu.om
}

\begin{abstract}
Fashion programs includes specified designing and making courses, such as fashion sketching and draping, other courses train the students on some skills which are related to fashion indirectly, such as fabrics dyeing, the model of the current study. Through observing, investigating, and within the experience of online teaching Fabric Dyeing at University of Nizwa 2020 Fall semester and 2021 Fall semester in pandemic time, the researcher found that the objectives concentrated on teaching definitions and procedures of dyeing, theoretically and practically. The objective of using dyed fabrics in the field of designing fashion is not included in the course syllabus, adding this objective (Dyed Fashion) unleashes and liberates creativity thinking and open the gate of producing creative fashion. Online learning which enhances critical thinking through sharing students the applications within LMS - learning management system, Moodle in the current study. Descriptive approach is followed, through three scales, measuring: Students' satisfaction of the current course, opinion scale for proposed dyed fashion designs and opinion scale for students' attitude toward the proposed lesson. The results indicate the actual need for developing the course and adding the proposed lesson (Dyed Fashion), the proposed lesson enhances the mental abilities of student and rising design sense, the proposed lesson is high potential for application through online teaching/learning
\end{abstract}

Keywords: Fabrics dyeing course, fashion design program, online teaching, teaching in pandemic, dyed fashion.

\section{INTRODUCTION}

Fabric Dyeing is one of Fashion Design Program courses, which combines theory with practice, in teaching this course, professors train students on creative thinking skills as fashion not fabric designers, it is considerable attitude in teaching this course and other courses which relate between fashion and other subjects. according to Peng, innovation education must pass throughout the entire method teaching, not only guide, and inspire the students' self-thought, but also let the students experience and confirm the success joy of innovation and creation by practicing. (Peng 2010) The innovation and creation are not limited in producing collection of fabric applications, but also in forming innovative fashion designs through their fabrics.

The objectives of the course concentrate on enhancing knowledge and skills of fabrics dyeing, the researcher found lack of guiding the students to apply their acquired knowledge and skills in fashion designing itself, according to (li Liang Liu 2019) (Gan 2019) (Wang 2009) creating fashion designs by the dyed fabrics, allow opportunities for students to participate in research training and actual practices before walking out of the campus, increasing their practical, innovative abilities. 
It's high considered in teaching Fabrics Dyeing course to train students on combining conceptual thinking with rational analysis, conceptual thinking will not be unrealistic only, focusing on forms, colours, and textures, but also effective and activate working together with rational thinking. (li 2011) (Gan 2019) According to Gan and Wang, students must maximize their development of creative thinking while learning the design rules. The main designing ability which is needed to be promoted is the ability of designing innovative fashion. (Gan 2019) (Wang 2009). The author taught the course before pandemic in Fall 2019, found out a real need of promoting the course throughout adding lessons that integrates dyeing skills with fashion designing skills, in Fall 2020 the main objective in teaching the course through Eduwave and Moodle -Management learning systems of University of Nizwa is involving the proposed skills through online teaching. The current study represents not only exploration in fabrics dyeing online-teaching, but also developing the major courses in pandemic.

\section{PROBLEMS}

1-What is students' satisfaction of the current course of Fabrics Dyeing, online teaching through LMSMoodle?

2 -What are students' opinions about the proposed fashion designs which using the dyed fabrics?

3 -What are fashion designers and professors review of the proposed fashion designs using dyed fabrics of the current study?

4 -What is students' attitude toward the lesson (Dyed fashion)?

5 -what is the proposed plan of the new lesson (Dyed fashion), theoretical/ practical- objectives/ contents?

\section{OBJECTIVES}

1 - Identifying the students' satisfaction of the current course of Fabrics Dying, which had been taught through Moodle management learning system Fall 2021.

2 -Designing creative fashion using the students dyed fabrics in Fall 2020.

3 -Review the student's portability to the proposed designed.

4 -Review the students' attitudes toward the proposed lesson entitle (Dyed fashion).

5 -Setting up the proposed lesson theoretical and practical frames, the objectives, and contents.

\section{SIGNIFICANCE}

The significance of the study represented in considering the current study as an experiment for directing the CLOs objective of each Fashion Design course toward rising the intellectual abilities and creative thinking of students as fashion designers.

\section{METHODOLOGY}

The study followed the descriptive approach in designing three scales:

1-Students' satisfaction rating scale of the current course of Fabrics Dyeing.

2-Opinion scale of proposed designs using dyed fabrics.

3-Opinion scale of students' attitudes toward the proposed lesson (Dyed fashion).

\subsection{Reliability and Validity of the Instruments}

\subsubsection{Students' Satisfaction Rating Scale of the Current Course of Fabrics Dyeing:}

The students' satisfaction rating scale of the current course of Fabrics Dyeing had been designed by the researcher on Likert's three-point scale, the scale includes two axes, the axes include (20) statements, (9) for the first axis considers the theoretical content of the current course, and (11) for the second axis considers the practical content of the current course. The reliability of the scale was verified by presenting it on some specialities, and then the scale has been put in its final form. The validity of the scale was verified by Cronbach's alpha as 0.93 , which confirms its validity for application. The highest score for the scale is (60) and the lowest score is (20). 


\subsubsection{Opinion Scale of Proposed Designs Using Dyed Fabrics}

A rating scale had been designed by the researcher, included (6) statements. The reliability of the scale was verified within presenting it to a group of supervisors, and then the scale was put in its final form. The validity of the opinion scale of proposed dyed fashion was verified by Cronbach's alpha as 0.87 , which approve its validity for application. The evaluating was measured by Likert's three-point scale, so that the highest score for the scale for the (9) proposed designs is (189) and the lowest score is (63).

\subsubsection{Opinion Scale of Students' Attitudes toward the Proposed Lesson (Dyed fashion):}

The students' opinion scale toward the proposed lesson had been designed by the researcher on Likert's three-point scale, the scale includes two axes, the axes include (10) statements, (4) for first axis, the theoretical contents of the current course, and (6) for the second axis, the practical contents of the proposed lesson. The reliability of the scale was verified by presenting it to a group of supervisors, and then the scale was put in its final form. The validity of the scale was verified by Cronbach's alpha as 0.95 , which confirms its validity for application. The highest score for the scale is (30) and the lowest score is (10).

\subsection{The Study Sample}

The study sample consisted of: (53) students in the fashion design program, Fall 2020 and Fall 2021- (5) faculty members in fashion design specialties - (5) faculty members in curricular sciences and teaching methods.

\section{LITERATURE REVIEW}

Current study proves the confirmation of Lehay, Keelin and Gaughran that design education students need for a pedagogical approach which promotes "designerly ways of thinking" (Lehay Keelin Gaughran 2009), the current study proposed a new lesson which enhance and unleash creativity thinking for Fashion Design Program students, the proposed lesson can be learned within online teaching.

Wang asked, are there any solutions that will lead design students to explore creative avenues from multiple perspectives? (Wang 2009) current study guides Fashion Program students to explore the boundaries through draping the dyed fabrics on mannequin, creating unprecedent fashion, MLS -management learning system- Moodle in current study is useful for allowing students and teacher sharing experiences and analyzing their applications. The current study results answered Wang's question, how we encourage students to develop internal critiques, promoting both risk-taking and flexibility throughout design process?

In addition, Alhajri results described the possibilities of enhancing creativity and innovative potentials within Omani students (Alhaji 2010). Alhajri students belong to graphic design however in current study students belong to fashion design, in both studies the students present high rate of willingness for developing the applications. Coruh's study developed a model for teaching technical specifications in fashion design education, the study's objective represented in integrating design and production with related technical specification (Coruh 2016), same objective of current study whereas the proposed lesson merges textile design with producing fashion.

Motta and Giovanni outlined the challenges young designers -students- are facing when passing the knowledge of manual technique and combining this knowledge with experimentations and innovation in teaching: knitwear, designing and producing. (Motta Giovani 2018). Current study the same objective relatively, focusing on directing the student's knowledge and skills of dyeing to design and produce innovative fashion.

Winters discussed how low-focused thinking "Affective and intuitive" can be used to promote high-focused thinking "logical and analytical" in art and design education. (Winters 2019). Current study examined and discussed promotion of both mental thinking and aesthetic sense for fashion students throughout directing the supreme objective of the courses to enhance student's capability as fashion designers.

Yi found that providing individualized education in higher education is a profound understanding of the true meaning of education. (Yi 2019). It is the appeal to adapt to the popularization, also an inevitable requirement for cultivating students' innovative ability, current study matches same objective.

While Harrison and Thomas's study examined the elements drive the learning experience for undergraduate students in a blended learning course, and suggested employing blended learning, the current study examines ultimately employing distance e-learning in teaching and learning Fashion Design courses. (Hrrison, Thomas, 2019) 


\section{7 (FABRICS DYEING) - CURRENT COURSE "FARM206"}

Students at University of Nizwa- Sultanate of Oman- College of Arts and Sciences - Department of Education and Culture Studies- Fine Arts Program- Fashion Design Specialty, learn the course of Fabrics Dyeing as a course of major requirements of the academic plan, the main objective of the course as follows: Introducing the principles of dyeing arts - learning a brief historical overview of the beginning of dyeing, the development, and influence in the field of textiles.

The course lessons as follows:

1-Historical overview of dyeing beginning and the development across different civilization.

2- Various dyeing methods during different historical ages.

3-Various dyeing process and techniques.

4-Implementing various methods of fabrics dyeing.

5-Training students with the ability of expressing themselves freely to select colours and designs, achieving values of visual textures through dyeing processes.

6-Applying different dyeing techniques on fabrics.

\section{THE STUDY PROPOSED DESIGNS}

Nine fashion designs had been dyed by Fashion Program Students/Fall2019 and had been designed by the course professor/author.

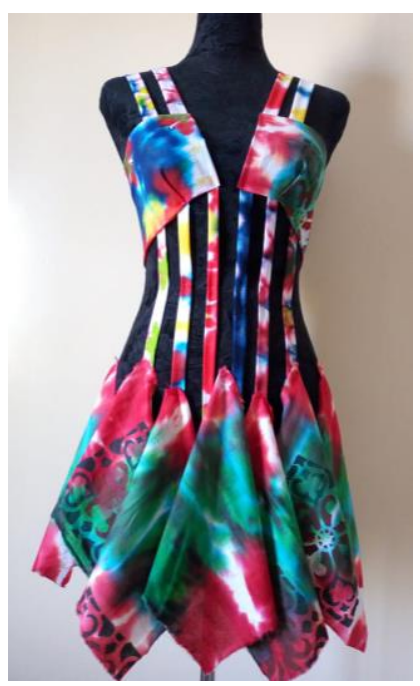

Fig. 1

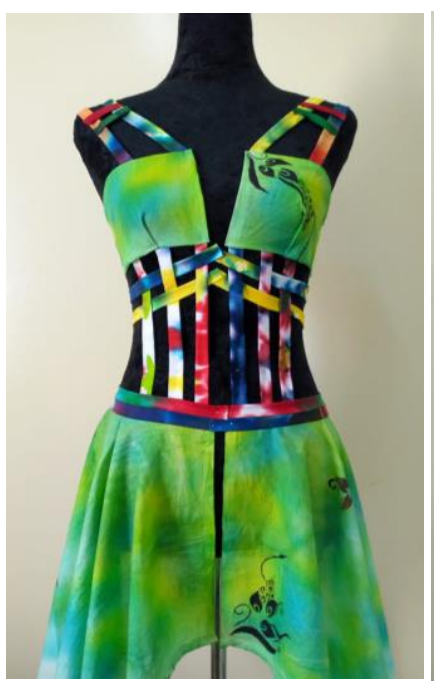

Fig. 2

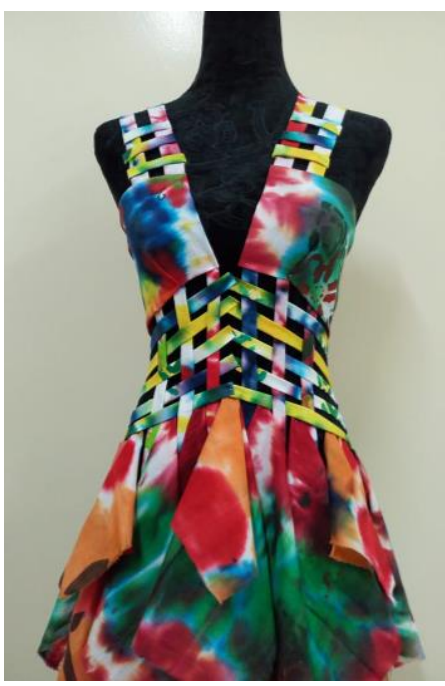

Fig. 3

Fig 1:3): Proposed designs by dyed fabrics- the fabrics are dyed by the students, are designed by the professor/author. 


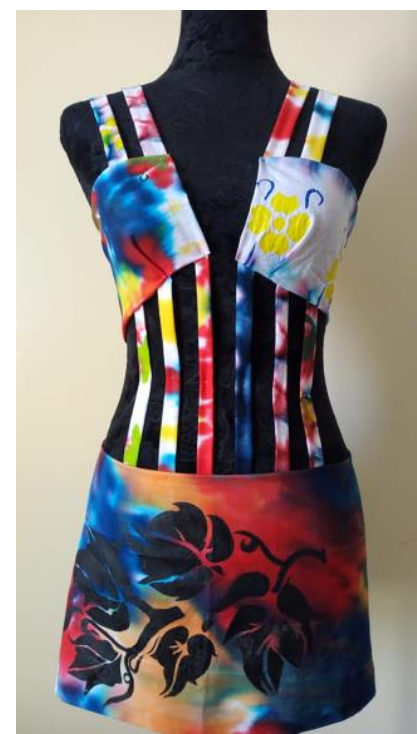

Fig. 4

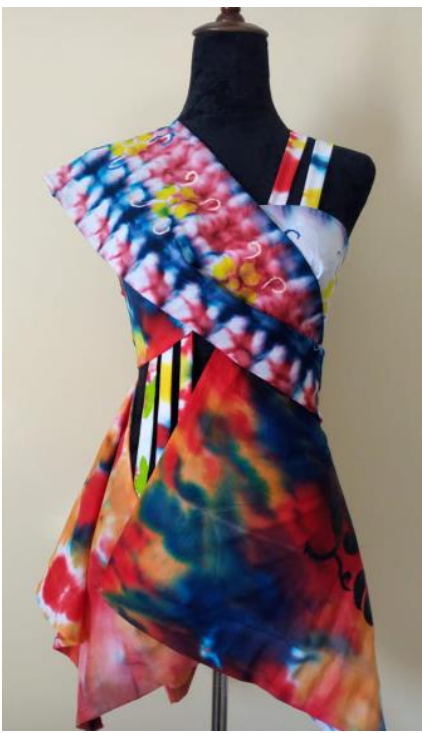

Fig. 5

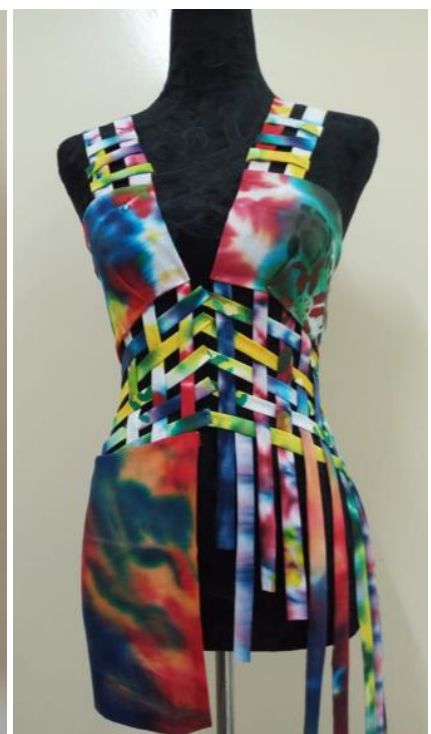

Fig. 6

Fig 4:6): Proposed designs by dyed fabrics- the fabrics are dyed by the students, are designed by the professor/author.

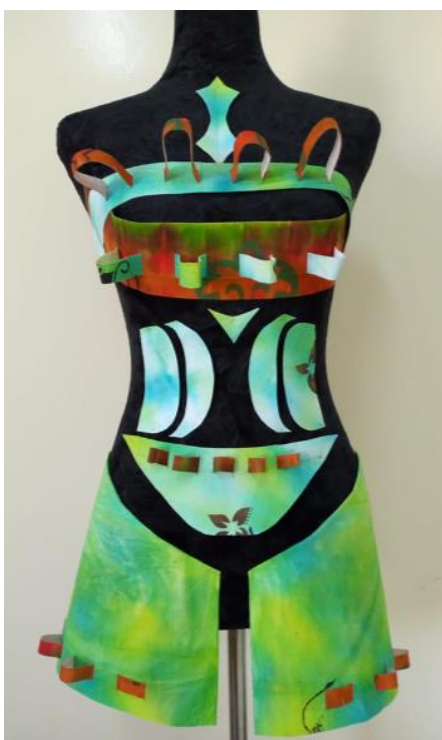

Fig. 7

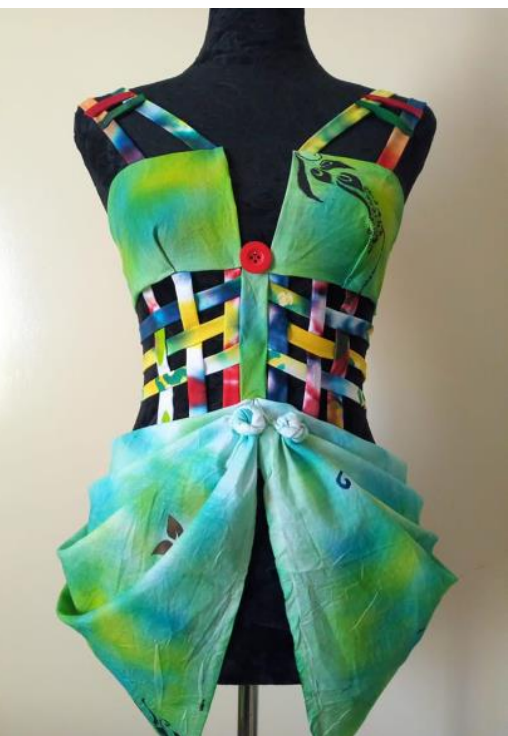

Fig. 8

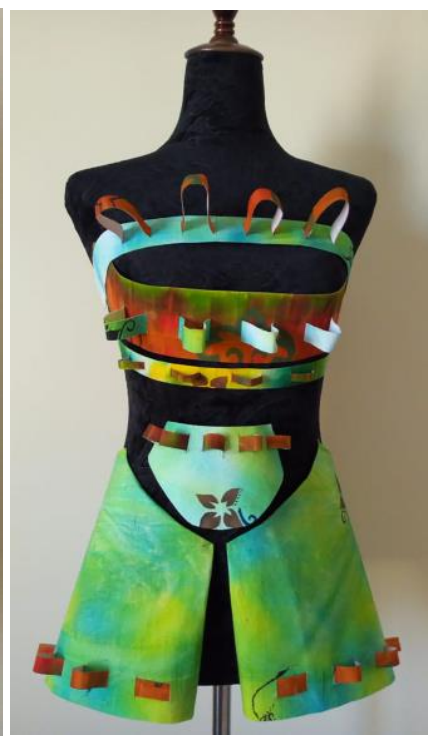

Fig. 9

Fig 7:9): Proposed designs by dyed fabrics- the fabrics are dyed by the students, are designed by the professor/author.

\section{STATISTICAL RESULTS}

Each question has been answered through a rating scale, as follows:

\subsection{First question}

1-What is students' satisfaction of the current course of Fabrics Dyeing, online teaching through LMSMoodle?

First axis of the Rating Scale measures the students' satisfaction of the theoretical content and the second axis for the practical skills, as follows: 
Table 1. Students Satisfaction Rating Scale of the current course Fabrics Dyeing.

\begin{tabular}{|c|c|c|c|c|c|c|}
\hline \multirow[t]{3}{*}{ Statement } & \multicolumn{6}{|c|}{$\begin{array}{l}\text { Response } \\
\mathrm{N}=53\end{array}$} \\
\hline & \multicolumn{2}{|c|}{ agree } & \multicolumn{2}{|c|}{ neutral } & \multicolumn{2}{|c|}{ disagree } \\
\hline & $\mathrm{N}$ & ratio & $\mathrm{N}$ & ratio & $\mathrm{N}$ & ratio \\
\hline \multicolumn{7}{|l|}{ Theoretical contents: } \\
\hline -I am Interested in learning the concepts of dyeing fabrics. & 52 & 98.11 & 1 & 1.88 & - & - \\
\hline -I accept recognition of different fabrics dyeing techniques. & 49 & 92.45 & 4 & 7.54 & - & - \\
\hline $\begin{array}{l}\text {-I look for the historical background of dyeing fabrics methods } \\
\text { in different countries and civilizations. }\end{array}$ & 48 & 90.56 & 5 & 9.43 & - & - \\
\hline $\begin{array}{l}\text { - I am interested in identifying the required tools for each } \\
\text { method of dyeing fabrics. }\end{array}$ & 48 & 90.56 & 5 & 9.43 & - & - \\
\hline $\begin{array}{l}-I \text { am sharing researching more about the dyeing methods and } \\
\text { the procedures for each style. }\end{array}$ & 50 & 94.33 & 3 & 5.66 & - & - \\
\hline $\begin{array}{l}\text {-I discuss my professor and colleagues the differences } \\
\text { between fabrics dyeing techniques. }\end{array}$ & 51 & 96.22 & 2 & 3.77 & - & - \\
\hline $\begin{array}{l}\text { - I participate in a discussion of the advantages and } \\
\text { disadvantages of each method of dyeing fabrics. }\end{array}$ & 50 & 94.33 & 3 & 5.66 & - & - \\
\hline $\begin{array}{l}\text {-I appreciate the value of my studies in fabrics dyeing course } \\
\text { as a fashion designer. }\end{array}$ & 49 & 92.45 & 5 & 9.43 & - & - \\
\hline $\begin{array}{l}-I \text { find the content of Fabrics Dyeing, the current course is } \\
\text { sufficient for me as a fashion designer }\end{array}$ & 19 & 35.84 & 3 & 5.66 & 31 & 58.49 \\
\hline \multicolumn{7}{|l|}{ Practical skills: } \\
\hline -I am interested in learning dyeing fabrics techniques. & 52 & 98.11 & 1 & 1.88 & - & - \\
\hline -I eagerly choose the pleat models I want to dye. & 53 & 100 & - & - & - & - \\
\hline $\begin{array}{l}\text {-I am interested in applying insulation with wax to get } \\
\text { innovative designs. }\end{array}$ & 53 & 100 & - & - & - & - \\
\hline $\begin{array}{l}\text {-I experiment hand knitting on fabric with different designs to } \\
\text { discover effects when dyeing. }\end{array}$ & 51 & 96.22 & 2 & 3.77 & - & - \\
\hline -I share my colleagues the dyeing experiments. & 49 & 92.45 & 3 & 5.66 & 1 & 1.88 \\
\hline -I eagerly follow marbling method when dyeing the fabric & 48 & 90.56 & 3 & 5.66 & 2 & 3.77 \\
\hline -I apply various dyeing techniques on fabric for discovering & 50 & 94.33 & 2 & 3.77 & 1 & 1.88 \\
\hline
\end{tabular}




\begin{tabular}{|l|l|l|l|l|l|l|}
\hline the aesthetic effects of each style. & & & & & & \\
\hline $\begin{array}{l}-I \text { am interested in researching on different methods of dyeing } \\
\text { fabrics. }\end{array}$ & 47 & 88.67 & 3 & 5.66 & 3 & 5.66 \\
\hline $\begin{array}{l}- \text { I value the learning of hand dyeing techniques for fashion } \\
\text { designer. }\end{array}$ & 47 & 88.67 & 4 & 7.54 & 2 & 3.77 \\
\hline $\begin{array}{l}-I \text { find the applications of dyeing techniques are enough for me } \\
\text { as a fashion designer. }\end{array}$ & 23 & 43.39 & 5 & 9.43 & 26 & 49.05 \\
\hline- I did not face problems in online learning of Fabrics Dyeing. & 49 & 92.45 & 3 & 5.66 & 1 & 1.88 \\
\hline
\end{tabular}

The statistics shows a high rate of appreciation the value of Fabrics Dyeing course as the students are fashion designers $92.45 \%$. Also, statistics indicates, the possibility of online teaching and learning of the course Fabrics Dyeing, 92.45\%.

\section{Second question}

2-What are students' opinions about the proposed fashion designs which using the dyed fabrics?

The proposed designs have been dyed by the students and have been constructed on dress stand by the course professor/author after ending Fall semester 2020. The questionnaire has been applied on the student of traditional learning Fall 2020 and the student of online learning 2021.

Table 2. Opinion scale of proposed fashion designs using dyed fabrics- by the students.

\begin{tabular}{|c|c|c|c|c|c|c|}
\hline \multirow[t]{4}{*}{ Statements } & \multicolumn{6}{|c|}{$\begin{array}{l}\text { Response } \\
\text { N. Students }=53 \quad \text { N. Designs }=9\end{array}$} \\
\hline & \multicolumn{2}{|c|}{ agree } & \multicolumn{2}{|c|}{ neutral } & \multicolumn{2}{|c|}{ disagree } \\
\hline & $\mathrm{N}$ & ratio & $\mathrm{N}$ & ratio & $\mathrm{N}$ & ratio \\
\hline & 471 & 98.74 & 6 & 1.25 & - & - \\
\hline $\begin{array}{l}\text {-The design applied one or more of fabrics dyeing } \\
\text { techniques successfully. }\end{array}$ & & & & & & \\
\hline $\begin{array}{l}\text {-The design achieves successful artistic values in terms of } \\
\text { distributing the composition elements (line - shape - colour } \\
\text { - texture) }\end{array}$ & 463 & 97.06 & 12 & 2.51 & 2 & 0.41 \\
\hline $\begin{array}{l}\text {-The design achieves successful artistic values in } \\
\text { composition principles (unity - proportionality - rhythm - } \\
\text { balance - contrast) }\end{array}$ & 469 & 98.32 & 7 & 1.46 & 1 & 0.02 \\
\hline $\begin{array}{l}\text {-The design is an innovative product in the field of } \\
\text { women's fashion. }\end{array}$ & 462 & 96.85 & 14 & 2.93 & 1 & 0.02 \\
\hline $\begin{array}{l}\text {-The design is flexible, so it can be redesigned in other } \\
\text { ways. }\end{array}$ & 459 & 96.22 & 15 & 3.14 & 3 & 0.62 \\
\hline -Inspiration can be taken from the proposed design in & 461 & 96.64 & 14 & 2.93 & 2 & 0.41 \\
\hline
\end{tabular}




\begin{tabular}{|c|c|c|c|c|c|c|}
\hline creating other commercial designs. & & & & & & \\
\hline $\begin{array}{l}\text {-I like the design and look forward to designing similar } \\
\text { applications with the fabrics that I dye. }\end{array}$ & 468 & 98.11 & 7 & 1.46 & 2 & 0.41 \\
\hline
\end{tabular}

The statistics indicate high scale of student's tendency to use the fabrics they dyed in experimenting creativity boundaries of fashion. $98.11 \%$ students like to design similar applications as the professor did by their dyed fabrics. In addition to this, the proposed designs have received a high degree of student acceptance in terms of design aesthetics, $97.06 \%$ for successful composition elements, and $98.32 \%$ for successful composition principles. Also, the questionnaire indicates that the proposed designs are highly flexible and can be applied in different styles, $96.22 \%$.

\section{Third question}

What are the fashion designers and instructors review of the proposed fashion designs using the dyed fabrics of the current study?

Table 3. Opinion scale of proposed designs using dyed fabrics- by fashion designers

\begin{tabular}{|c|c|c|c|c|c|c|}
\hline \multirow[t]{4}{*}{ Phrase } & \multicolumn{6}{|c|}{$\begin{array}{l}\text { Response } \\
\text { N. Specialists }=10\end{array}$} \\
\hline & \multicolumn{2}{|c|}{ agree } & \multicolumn{2}{|c|}{ neutral } & \multicolumn{2}{|c|}{ disagree } \\
\hline & $N$ & ratio & $\mathrm{N}$ & ratio & $\mathrm{N}$ & ratio \\
\hline & 89 & 98.88 & 2 & 2.22 & - & - \\
\hline $\begin{array}{l}\text {-The design applied one or more of the fabrics dyeing } \\
\text { techniques successfully. }\end{array}$ & & & & & & \\
\hline $\begin{array}{l}\text {-The design achieves successful artistic values in terms } \\
\text { of distributing the elements of the composition (line - } \\
\text { shape - colour - texture) }\end{array}$ & 83 & 92.22 & 6 & 6.66 & 1 & 0.11 \\
\hline $\begin{array}{l}\text {-The design achieves successful artistic values in the } \\
\text { composition principles (unity - proportionality - rhythm - } \\
\text { balance - contrast) }\end{array}$ & 82 & 91.11 & 5 & 5.55 & 3 & 3.33 \\
\hline $\begin{array}{l}\text {-The design is an innovative product in the field of } \\
\text { women's fashion. }\end{array}$ & 82 & 91.11 & 3 & 3.33 & 5 & 5.55 \\
\hline $\begin{array}{l}\text {-The design is flexible, it could be redesigned in other } \\
\text { styles. }\end{array}$ & 80 & 88.88 & 7 & 7.77 & 3 & 3.33 \\
\hline $\begin{array}{l}\text { - The proposed fashion designs allow inspiration in } \\
\text { creating other commercial designs. }\end{array}$ & 83 & 92.22 & 7 & 7.77 & - & - \\
\hline
\end{tabular}

The proposed designs have received a high degree of specialist's acceptance in terms of design aesthetics, $92.22 \%$ for successful composition elements, and $91.11 \%$ for successful composition principles. Also, the questionnaire indicates that the proposed designs are highly flexible and can be applied in different styles, $88.88 \%$.

\section{Fourth question}

4-What is students' attitude toward the lesson (Dyed fashion)? First axis of the opinion Scale of theoretical 
content and the second axis for the practical content, as follows:

Table 4. Opinion Scale of students' attitude toward the proposed lesson

(Dyed Fashion)

\begin{tabular}{|c|c|c|c|c|c|c|}
\hline \multirow[t]{3}{*}{ Statements } & \multicolumn{6}{|c|}{$\begin{array}{l}\text { Response } \\
\text { N. Students }=53\end{array}$} \\
\hline & \multicolumn{2}{|c|}{ agree } & \multicolumn{2}{|c|}{ neutral } & \multicolumn{2}{|c|}{ disagree } \\
\hline & $\mathrm{N}$ & ratio & $\mathrm{N}$ & ratio & $\mathrm{N}$ & ratio \\
\hline \multicolumn{7}{|l|}{ Theoretical content } \\
\hline $\begin{array}{l}\text {-I am looking forward to learning the experiences of the } \\
\text { fashion designers in employing dyed fabrics. }\end{array}$ & 52 & 98.11 & 1 & 1.88 & - & - \\
\hline -I am looking to research dyeing fashion collections. & 50 & 94.33 & 3 & 5.66 & - & - \\
\hline -I am looking to analyse the aesthetics of dyed fashion. & 53 & 100 & - & - & - & - \\
\hline $\begin{array}{l}\text {-I find that analysing of fabrics dyeing designs } \\
\text { reinforces my ideas in this direction. }\end{array}$ & 52 & 98.11 & 1 & 1.88 & - & - \\
\hline $\begin{array}{l}\text {-I find online learning is largely successful in learning } \\
\text { theoretical frames of fashion major course. }\end{array}$ & 47 & 88.67 & 2 & 3.77 & 4 & 7.54 \\
\hline \multicolumn{7}{|l|}{ Practical Framework } \\
\hline $\begin{array}{l}\text {-I am looking to examine designing fashion through the } \\
\text { fabrics I dyed. }\end{array}$ & 52 & 98.11 & 1 & 1.88 & - & - \\
\hline $\begin{array}{l}\text {-I am looking forward to discussing my design ideas } \\
\text { with my colleagues. }\end{array}$ & 51 & 96.22 & 1 & 1.88 & 1 & 1.88 \\
\hline -I apply fashion designing through my dyed fabrics. & 53 & 100 & - & - & - & - \\
\hline $\begin{array}{l}\text {-I find a necessity of proposing fashion designs } \\
\text { through the dyed fabrics. }\end{array}$ & 52 & 98.11 & 1 & 1.88 & - & - \\
\hline $\begin{array}{l}\text {-I am interested on enhancing the skills of creating } \\
\text { thinking through dyed fabrics designing. }\end{array}$ & 52 & 98.11 & 1 & 1.88 & - & - \\
\hline $\begin{array}{l}\text {-I find the main objective of studying dyeing methods is } \\
\text { to propose fashion designs. }\end{array}$ & 51 & 96.22 & 2 & 3.77 & - & - \\
\hline $\begin{array}{l}\text {-Online learning did not hinder the development of } \\
\text { mental capabilities and artistic sense. }\end{array}$ & 45 & 84.9 & 5 & 9.43 & 3 & 5.66 \\
\hline
\end{tabular}

The statistics indicate a high rate of Students' willingness to receive information and skills related to the Fashion Design major through online learning, and to develop their abilities as fashion designers by designing fashion applications on what they dyed during their learning. The statistical results also show the students 'readiness to receive the proposed lesson, which aims to provide knowledge and practical skills. 


\section{Fifth question}

5-what is the proposed plan of the new lesson (Dyed fashion), theoretical/ practical- objectives/ contents?

Table 5: The proposed lesson (Dyed Fashion)

\begin{tabular}{|c|c|c|c|}
\hline $\begin{array}{l}\text { The objectives } \\
\text { (theoretical) }\end{array}$ & $\begin{array}{l}\text { The content } \\
\text { (theoretical) }\end{array}$ & The objective (practical) & $\begin{array}{l}\text { The content } \\
\text { (practical) }\end{array}$ \\
\hline $\begin{array}{l}\text { The student } \\
\text { analyses different } \\
\text { models of fashion } \\
\text { that employ } \\
\text { dyeing } \\
\text { techniques in } \\
\text { production. }\end{array}$ & $\begin{array}{l}\text { Presenting and analysing } \\
\text { of different models of } \\
\text { dyeing applications in the } \\
\text { field of fashion design. }\end{array}$ & $\begin{array}{l}\text { To activate the creative } \\
\text { abilities of the student } \\
\text { through proposing dyed } \\
\text { fashion. }\end{array}$ & $\begin{array}{l}\text { experimenting fashion } \\
\text { designing through dyed } \\
\text { fabric structuring. }\end{array}$ \\
\hline $\begin{array}{l}\text { The student } \\
\text { analyses some } \\
\text { fashion shows } \\
\text { that depend on } \\
\text { the technique of } \\
\text { dyeing fabrics. }\end{array}$ & $\begin{array}{l}\text { Analysing of dyeing } \\
\text { methods used in designs } \\
\text { (knotting - fastening - } \\
\text { marbling - hand sewing - } \\
\text { folding). }\end{array}$ & $\begin{array}{l}\text { The student shall employ } \\
\text { dyeing techniques in } \\
\text { designing a creative } \\
\text { commercial product. }\end{array}$ & $\begin{array}{l}\text { Designing and } \\
\text { implementing of a simple } \\
\text { commercial design from } \\
\text { hand-dyed fabrics. }\end{array}$ \\
\hline
\end{tabular}

\section{CONCLUSION}

In pandemic time through online teaching professors are required to teach and continue developing the courses, pandemic time which humanity faced since December 2019 taught us that teaching and learning will not be as before, one of the real challenges is Fashion Design courses, which needs real existence of students with their professor's face to face. In current study the author examine the capability of teaching fashion major courses ultimately through online learning, specially that fashion design depends on learning many practical skills, initializing students for being fashion designers, the current study applied the experiment on course of "Fabrics Dyeing", current study recommends to follow the online learning in teaching similar courses, in addition to develop fashion related courses to enhance creative thinking of students for being fashion designers.

The course of (Fabrics Dyeing) had been taught in Fall 2020 by the author in traditional learning, and online at pandemic in Fall 2021 the author re-taught the course, applied the study questionnaire, looking forward to applying the proposed lesson -within current study- on Spring 2023. The professor/author followed synchronize learning in teaching both the theoretical and practical frameworks of the course. In advancing vision for teaching the course, the author proposed a lesson entitle (Dyed Fashion) and designed three rating scales for measuring: 1- Students Satisfaction of the current course Fabrics Dyeing, 2- Opinion scale of proposed designs using dyed fabrics, 3- students' attitude toward the proposed lesson (Dyed Fashion) the results indicate a wide scale of student's tendency towards the proposed lesson, which will be applied Spring 2022.

\section{ACKNOWLEDGEMENT}

I wish to acknowledge University of Nizwa for providing the support of online teaching in pandemic time. 
Also, I appreciate my students at University of Nizwa for their kind response and support in performing the experiment and for the effort in online learning for practical courses in the Covid-19 pandemic time.

\section{REFERENCE LIST}

Alhajri, Salman Amur. (2010). The Importance of Creativity in Teaching Graphic Design in Arab World. Design Principles and Practices: An International Journal-Annual Review 4 (1): 59-70. doi:10.18848/1833-1874/CGP/v04i01/37819.

Coruh, Esen. (2016). Teaching technical specifications in fashion design education. New Trends and Issues Proceedings on Humanities and Social Sciences. 2(1). 356-363. doi.org/10.18844/gjhss.v2i1.319

Gan, Jingxiu. (2019). Research on the Conceptual Teaching in Design College. IEEE Eurasia Conference on IOT, Communication and Engineering (ECICE). Yunlin, Taiwan. 129-131, doi: 10.1109/ECICE47484.2019.8942779.

Harrison, Elgloria, and Morris Thomas. (2019). Employing the ENHANCE Learning Model to Inform a HighImpact Course Design. Ubiquitous Learning: An International Journal 12 (3): 9-18. doi:10.18848/18359795/CGP/v12i03/9-18

Leahy, Keelin, and William Gaughran. (2009). Acknowledging and Developing a Design and Creative Ability of Students within the Various Social Settings of Irish Second Level Education System. Design Principles and Practices: An International Journal-Annual Review 3 (3): 43-68. doi:10.18848/18331874/CGP/v03i03/37677.

Li, Li. Liang, Mingjie and Liu, Zhen. (2019). Interdisciplinary Teaching of Basic Architectural Design Knowledge under the Environmental Design Major: An Exploration. IEEE International Conference on Engineering, Technology and Education. doi: 10.1109/TALE48000.2019.9225979

Motta, Martina, and Giovanni Maria Conti. (2018). Teaching Knitwear Design: Design Practice for Traditional Manual Knowledge Innovation. The International Journal of Design Education 12 (2): 13-23. doi:10.18848/2325-128X/CGP/v12i02/13-23.

Peng, Guobin. Peng, Runhong. (2010). Teaching and Research about Design Methodology in Animation Design Specialty. IEEE 11th International Conference om Computer-Aided Industrial Design \& Conceptual Design- CAIDCD. 1. doi: 10.1109/CAIDCD.2010.5681366.

Wang, Wujun. (2009). An Experimental Design Matrix that Prevents Narrow Minds in Design Education. Design Principles and Practices: An International Journal-Annual Review 3 (4): 249-258. doi:10.18848/1833-1874/CGP/v03i04/37730.

Winters, Tara Michelle. (2019). Not Thinking on Purpose: The Significance of Low-Focused Thinking in Creative Education. The International Journal of Design Education 13 (3): 1-11. doi:10.18848/2325128X/CGP/v13i03/1-11.

Yi, Jun. (2019). Research on Practice Teaching of Environmental Design Major Internship Course Against the Background of Individualized Education. Advances in Social Science, Education and Humanities Research, 341: 935-938. doi:125916241\%20(1).pdf

You, Lei. (2011). Reform and innovation on curriculum of environmental art design major using computer technology. International Conference on Business Management and Electronic Information, Guangzhou China187-190. doi: 10.1109/ICBMEI.2011.5916903. 